\title{
Understanding Clinical Inertia in Diabetes
}

\author{
Raveendran Arkiath Veettil ${ }^{1, \oplus}$ \\ ${ }^{1}$ Department of Medicine, Government Medical College, Manjeri, \\ Kottayam, Kozhikode, Kerala, India
}

\begin{abstract}
Address for correspondence Raveendran Arkiath Veettil, MD, Specialist in Internal Medicine Badr Al Samaa, Barka, Sultanate of Oman (e-mail: raveendranav@yahoo.co.in).
\end{abstract}
Abstract
Keywords
- clinical inertia
- clinical inertia at patient care level
- clinical inertia at population
- diagnostic inertia
- reverse clinical inertia
- therapeutic inertia

Clinical inertia is common in the management of asymptomatic chronic disease such as diabetes, hypertension, and dyslipidemia. In case of diabetes, it exists in all stages of management of diabetes. It can be at population level or at patient level. In addition to assessment of glycemic control with blood glucose and hemoglobin $\mathrm{A}_{1 \mathrm{C}}\left(\mathrm{HbA}_{1 \mathrm{C}}\right)$ monitoring, emerging concepts such as "glycemic variability" and "time in range" are increasingly used. Inability to reduce "glycemic variability" and attain "time in range" targets also contributes to clinical inertia.

\section{Introduction}

Various landmark trails showed that tight glycemic control reduces diabetes-related long-term complications. However, a significant proportion of people with diabetes on regular treatment and follow-up fail to achieve treatment target. Clinical inertia is one of the major contributing factors for this.

\section{Clinical Inertia}

Clinical inertia is defined as inability or failure of health care providers to initiate or intensify therapy when it is actually indicated. ${ }^{1}$ In other words, it is "recognition of the problem, but failure to act."

It is an "evidence practice gap." Evidence practice gap is defined as the "difference between what we know from the best available research evidence and what actually happens in current practice." In other words, it is the gap between the best current practice recommendation and the level of care the patient received. In people with suboptimal glycemic control, if one is adding an agent that is unlikely to achieve glycemic target, that also contributes to clinical inertia. ${ }^{3}$

The term "clinical inertia" was first coined by Phillips et al in 2001, and the term "therapeutic inertia" was introduced by
Okonofua et al in 2006. ${ }^{1,4}$ Various terms such as "therapeutic inertia," "physician inertia," and "diagnostic inertia" are synonymously used with clinical inertia. However, some experts define it differently. Diagnostic inertia is defined as failure to consider the diagnosis, when it really exists, ${ }^{5}$ whereas therapeutic inertia is defined as failure of providers to begin new medications or increase dosages of existing medications when an abnormal clinical parameter is recorded. ${ }^{4}$

Another term related to this is "clinical myopia." The failure to give preference to the long-term benefits of treatment intensification may represent a common mechanism underlying both patient's nonadherence and physician's clinical inertia. Such failures are called "clinical myopia."6 Therapeutic momentum is defined as the reluctance to step down or withdraw therapy when further prescription is not required or not supported by evidence. ${ }^{7}$

Clinical inertia also may apply to the failure of physicians to stop or reduce therapy which is no longer required. Such inertia is called reverse clinical inertia. ${ }^{8}$ Failure to de-intensify therapy when appropriate is important in people with frail diabetes phenotype, which includes elderly individuals; underweight individuals; those having long duration of diabetes; and those having underlying heart disease, stroke, or renal insufficiency. ${ }^{9}$
DOI https://doi.org/

10.1055/s-0039-1694300 ISSN 2321-0656.
License terms

(요 (1) $\Theta \circledast$ 
Clinical inertia exists in all stages of development of diabetes starting from the development of risk factors, stage of pre-diabetes to the stage of end-organ failure due to diabetes $^{10}$ ( $\mathbf{- T a b l e ~} \mathbf{1}$ ). Health care professional has got a pivotal role in the prevention and progression of diabetes at each stage. Population-based approach to prevent the development of risk factors reduces the chance of development of pre-diabetes and overt diabetes in the society. ${ }^{10}$ Early screening of those with risk factors helps diagnose diabetes early. Proper treatment of diabetes during initial years of diagnosis is associated with long-term cardiovascular beneficial effect that is called "legacy effect." Strict glycemic control and control of other cardiovascular risk factors reduce the risk of diabetes-related long-term complications. In people with long-term diabetes, screening for long-term complication results in early identification of the complication and opportunity to prevent its further progression. ${ }^{10}$ In patients with long-term complications, aggressive management results in reduction of morbidity and mortality. Clinical inertia at all these stages results in increase in the global burden of diabetes and diabetes-related complications. ${ }^{10}$

Clinical inertia exists not only in the area of glycemic control but also in glycemic monitoring and identification and treatment of chronic complications of diabetes. In people

Table 1 Overview of clinical inertia in the management of diabetes

\begin{tabular}{|c|}
\hline $\begin{array}{l}\text { Overview of clinical inertia in the management of } \\
\text { diabetes }\end{array}$ \\
\hline Clinical inertia at population level \\
\hline $\begin{array}{l}\text { Clinical inertia to follow healthy lifestyle, e.g., eating habits, } \\
\text { physical activity }\end{array}$ \\
\hline $\begin{array}{l}\text { Clinical inertia to screen for diabetes and other lifestyle } \\
\text { disorders }\end{array}$ \\
\hline Clinical inertia at patient level \\
\hline Clinical inertia to initiate and intensify lifestyle modification \\
\hline $\begin{array}{l}\text { Clinical inertia to initiate and intensify oral antidiabetic } \\
\text { agents }\end{array}$ \\
\hline $\begin{array}{l}\text { Clinical inertia to initiate and intensify injectable antidia- } \\
\text { betic agents }\end{array}$ \\
\hline Clinical inertia to monitor glycemic status regularly \\
\hline $\begin{array}{l}\text { Clinical inertia to screen for long-term complications of } \\
\text { diabetes }\end{array}$ \\
\hline $\begin{array}{l}\text { Clinical inertia to initiate and intensify treatment for long- } \\
\text { term complications of diabetes }\end{array}$ \\
\hline $\begin{array}{l}\text { Clinical inertia to modify antidiabetic medication in people } \\
\text { with long-term complications of diabetes }\end{array}$ \\
\hline $\begin{array}{l}\text { Clinical inertia to redefine treatment targets in frail diabe- } \\
\text { tes phenotype }\end{array}$ \\
\hline $\begin{array}{l}\text { Clinical inertia to deescalate therapy in frail diabetes } \\
\text { phenotype }\end{array}$ \\
\hline $\begin{array}{l}\text { Clinical inertia to screen for other comorbid conditions, } \\
\text { e.g., hypertension, dyslipidemia in people with diabetes }\end{array}$ \\
\hline $\begin{array}{l}\text { Clinical inertia to initiate and intensify treatment for other } \\
\text { comorbid conditions, e.g., hypertension, dyslipidemia in } \\
\text { people with diabetes }\end{array}$ \\
\hline
\end{tabular}

with diabetes, management of other cardiovascular risk factors such as hypertension, dyslipidemia, and obesity is also important. Clinical inertia exists in the management of these conditions contributing to increased risk of cardiovascular morbidity and mortality. Clinical inertia exists in all the stages of management of diabetes including initiation of lifestyle modification, initiation, and intensification of oral antidiabetic drugs and initiation and intensification of injectable agents including insulin.

\section{Clinical Inertia at Population and at Patient Care Level}

Depending on the level of clinical inertia, it can be of two types: clinical inertia at population level and clinical inertia at patient care level (-Table 2). Creating awareness about healthy lifestyle, prevention of development of risk factors such as obesity, prevention of development and progression of pre-diabetes, and early case detection by population-based screening is mainly done at community level. However, in people with diabetes; failure to intensify therapy contributes

Table 2 Comparison between clinical inertia at population level and at patient care level

\begin{tabular}{|c|c|}
\hline $\begin{array}{l}\text { Clinical inertia at } \\
\text { population level }\end{array}$ & $\begin{array}{l}\text { Clinical inertia at patient } \\
\text { care level }\end{array}$ \\
\hline $\begin{array}{l}\text { Failure to improve aware- } \\
\text { ness about healthy lifestyle } \\
\text { and need for screening of } \\
\text { lifestyle disorders in the } \\
\text { population }\end{array}$ & \multirow[t]{2}{*}{$\begin{array}{l}\text { Failure to intensify therapy } \\
\text { in people with diabetes }\end{array}$} \\
\hline $\begin{array}{l}\text { Failure to motivate people } \\
\text { to lead healthy lifestyle and } \\
\text { early disease screening }\end{array}$ & \\
\hline $\begin{array}{l}\text { Reflect the quality of pre- } \\
\text { ventive care }\end{array}$ & $\begin{array}{l}\text { Reflect the quality of pa- } \\
\text { tient care }\end{array}$ \\
\hline $\begin{array}{l}\text { Achieved mainly with } \\
\text { nonpharmacologic in- } \\
\text { terventions and lifestyle } \\
\text { modifications }\end{array}$ & $\begin{array}{l}\text { Achieved mainly with phar- } \\
\text { macologic therapy }\end{array}$ \\
\hline $\begin{array}{l}\text { Inertia in activities like } \\
\text { creating awareness about } \\
\text { healthy lifestyle in the } \\
\text { society, prevention of } \\
\text { development of risk factors, } \\
\text { e.g., obesity, prevention of } \\
\text { development and progres- } \\
\text { sion of pre-diabetes, early } \\
\text { case detection by popula- } \\
\text { tion-based screening }\end{array}$ & $\begin{array}{l}\text { Inertia in activities, e.g., } \\
\text { initiation and intensification } \\
\text { of antidiabetic medications, } \\
\text { regular monitoring of glyce- } \\
\text { mic control, monitoring and } \\
\text { treatment of other comor- } \\
\text { bidities, and diabetes-relat- } \\
\text { ed complications }\end{array}$ \\
\hline $\begin{array}{l}\text { Inertia in population-based } \\
\text { interventions }\end{array}$ & $\begin{array}{l}\text { Inertia in hospital-/clin- } \\
\text { ic-based interventions }\end{array}$ \\
\hline $\begin{array}{l}\text { Tackling clinical inertia } \\
\text { reduces the burden of dia- } \\
\text { betes in the population }\end{array}$ & $\begin{array}{l}\text { Tackling clinical inertia } \\
\text { reduces the morbidity and } \\
\text { mortality associated with } \\
\text { poor glycemic control }\end{array}$ \\
\hline $\begin{array}{l}\text { Tackling clinical inertia } \\
\text { reduces the risk of other } \\
\text { lifestyle problems, e.g., } \\
\text { hypertension, dyslipidemia, } \\
\text { and obesity }\end{array}$ & $\begin{array}{l}\text { Tackling clinical inertia } \\
\text { reduces the risk of diabe- } \\
\text { tes-related complications } \\
\text { and associated comorbid- } \\
\text { ities, e.g., hypertension, } \\
\text { dyslipidemia, etc. }\end{array}$ \\
\hline
\end{tabular}




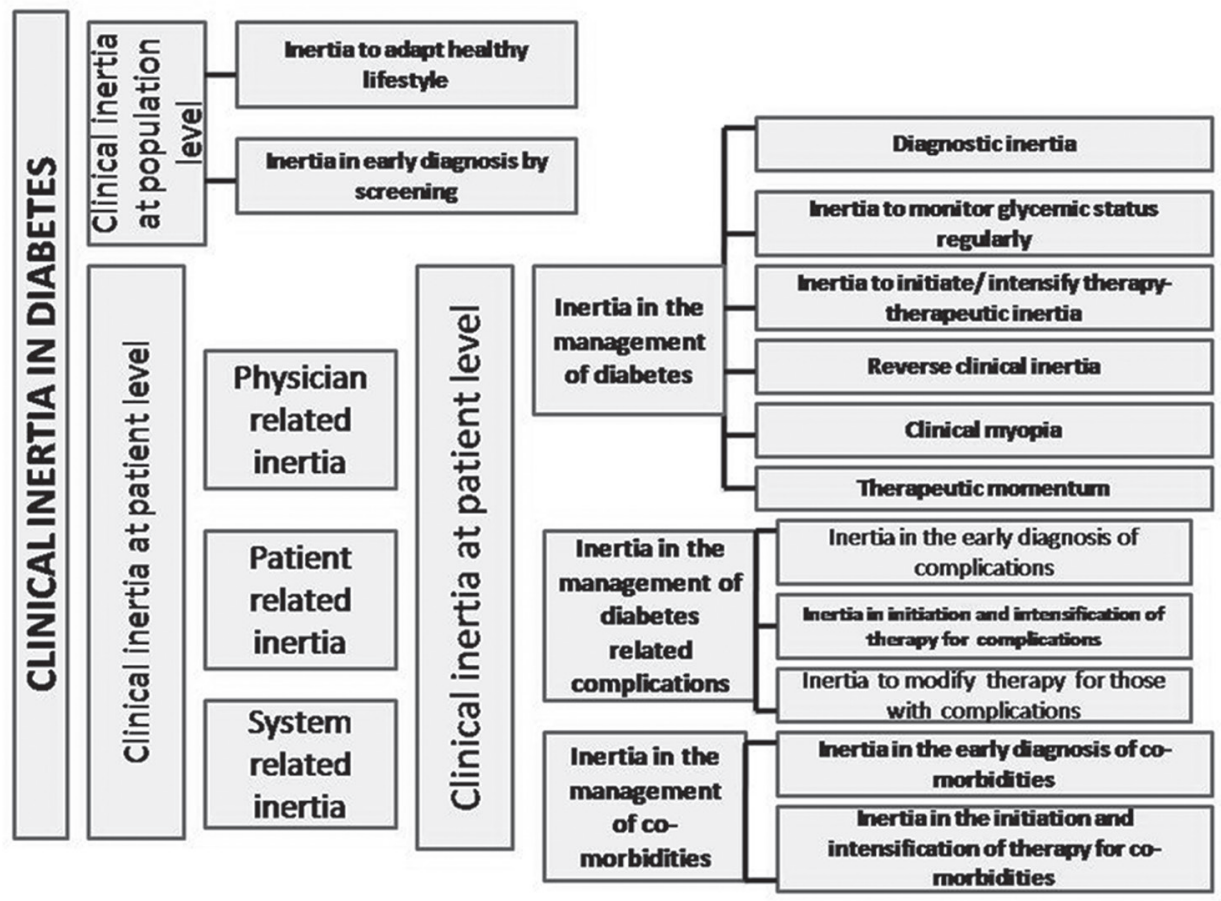

Fig. 1 Different aspects of clinical inertia.

to clinical inertia at patient care level ( - Fig. 1). It can be due to provider-, patient-, or system-related issues. ${ }^{11}$ Clinical inertia at population level usually reflects inadequate preventive care where as clinical inertia at patient level reflects inadequate patient care.

The excess blood sugar level to which people with diabetes get exposed because of clinical inertia is called "glycemic burden." The part of glycemic burden after the first out of target hemoglobin $\mathrm{A}_{1 \mathrm{C}}\left(\mathrm{HbA}_{1 \mathrm{C}}\right)$ is called "avoidable glycemic burden," and the remaining part of the glycemic burden is called "unavoidable glycemic burden."12 Early diagnosis and timely initiation and intensification of antidiabetic therapy reduce glycemic burden. ${ }^{13}$ Inability to monitor glycemic status regularly delays treatment intensification resulting in excess "glycemic burden."

\section{Emerging Concepts Regarding Clinical Inertia}

In some people with diabetes, blood sugar values fluctuate widely. The degree of fluctuation of blood glucose level is called glycemic variability (GV). Various studies show that frequent or large glucose fluctuations may independently contribute to diabetes-related complications. ${ }^{14}$ Therefore, inability to reduce GV also contributes to clinical inertia.

Time in range (TIR) is another new concept that is defined as a measure of time where the blood glucose remains within the proposed target range..$^{15}$ Therefore, inability to attain the TIR targets also contributes to clinical inertia.

Clinical inertia contributes to poor glycemic control in people with diabetes, resulting in exposure to high blood sugar level for months to years. In other words, clinical inertia results in increased risk of development of various complications. One analysis showed that $80 \%$ of heart attacks are the result of clinical inertia in the management of diabetes, hypertension, and dyslipidemia. ${ }^{11}$ Addressing the issues of clinical inertia in diabetes helps reduce diabetes-related morbidity and mortality.

\section{Conclusion}

Clinical inertia exists in all stages of management of diabetes. Clinical inertia at population level reflects the quality of preventive care where as clinical inertia at patient level reflects the quality of treatment offered to the patients. Addressing the issues of clinical inertia helps reduce diabetes-related complications.

\section{Funding}

None.

\section{Conflict of Interest}

None declared.

\section{References}

1 Phillips LS, Branch WT, Cook CB, et al. Clinical inertia. Ann Intern Med 2001;135(9):825-834

2 National Institute of Clinical Studies, Evidence-Practice Gaps Report. Vol. 1. Melbourne, Australia: NICS 2003.

3 Byrnes PD. Why haven't I changed that? Therapeutic inertia in general practice. Aust Fam Physician 2011;40(1-2):24-28

4 Okonofua EC, Simpson KN, Jesri A, Rehman SU, Durkalski VL, Egan BM. Therapeutic inertia is an impediment to achieving the Healthy People 2010 blood pressure control goals. Hypertension 2006;47(3):345-351 
5 Gil-Guillén V, Orozco-Beltrán D, Pérez RP, et al. Clinical inertia in diagnosis and treatment of hypertension in primary care: quantification and associated factors. Blood Press 2010;19(1):3-10

6 Reach G. Patient non-adherence and healthcare-provider inertia are clinical myopia. Diabetes Metab 2008;34(4 Pt 1): 382-385

7 Rodrigo C, Amarasuriya M, Wickramasinghe S, Constantine GR. Therapeutic momentum: a concept opposite to therapeutic inertia. Int J Clin Pract 2013;67(1):97-98

8 Giugliano D, Maiorino MI, Bellastella G, Esposito K. Clinical inertia, reverse clinical inertia, and medication non-adherence in type 2 diabetes. J Endocrinol Invest 2019;42(5):495-503 Review

9 Khunti K, Davies MJ. Clinical inertia-Time to reappraise the terminology? Prim Care Diabetes 2017;11(2):105-106

10 Mohan V. Expanding the concept of 'clinical inertia' in diabetes. J Diabetol 2019;10:1-3
11 O'Connor PJ, Sperl-Hillen JM, Johnson PE, Rush WA, Biltz G, Clinical inertia and outpatient medical errors. Agency for Healthcare Research and Quality. April 2005. Available at: http://www.ahrq.gov/downloads/pub/advances/vol2/OConnor.pdf. Accessed July 18, 2019.

12 Brown JB, Nichols GA, Perry A. The burden of treatment failure in type 2 diabetes. Diabetes Care 2004;27(7):1535-1540

13 Unnikrishnan R, Mohan V. Why screening for type 2 diabetes is necessary even in poor resource settings. J Diabetes Complications 2015;29(7):961-964

14 Satya Krishna SV, Kota SK, Modi KD. Glycemic variability: clinical implications. Indian $\mathrm{J}$ Endocrinol Metab 2013;17(4):611-619

$15 \mathrm{Lu} \mathrm{J}$, Ma X, Zhou J, et al. Association of time in range, as assessed by continuous glucose monitoring, with diabetic retinopathy in type 2 diabetes. Diabetes Care 2018;41(11):2370-2376 